\title{
Strategically Leveraging Corporate Social Responsibility: A Corporate Branding Perspective
}

\author{
Christine Vallaster \\ Adam Lindgreen \\ François Maon
}

Corporate social responsibility (CSR) is changing the rules of branding but it is unclear how. While the literature offers a range of approaches seeking insight to how to manage CSR-related issues, practitioners are left in a state of confusion when having to decide on how to tackle CSR in a way that benefits both the corporate brand and society at large. Based on qualitative empirical research, this article offers a framework for companies to address CSR and their brands strategically, whether as entrepreneurs, performers, vocal converts, or quietly conscientious. We define these categories according to the level of involvement, integration, and the key initiator of the CSR focus. This article concludes with suggestions practitioners should keep in mind when aiming to balance stakeholder tensions and to achieve consistency in their corporate branding and CSR efforts. (Keywords: Brand management, Corporate social responsibility, Qualitative research, Corporate identity, Corporate brand, Corporate marketing)

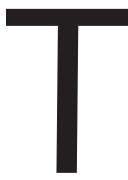

he search for meaning is not limited to philosophers and sages. Increasingly, consumers-as well as employees, shareholders, the financial community, media, and nongovernmental organizations (NGOs)yearn for something meaningful in their consumption activities and look to companies to offer meaning by exemplifying credible, value-laden, and authentic traits. In response, branding efforts extend beyond the brand to encompass well-defined sets of values that might resonate with diverse audiences. ${ }^{1}$ For example, many global corporate brands embrace corporate social responsibility (CSR). Axel Springer, one of Germany's largest media companies, promises that "integrity guides our daily work," and BMW stopped racing because, among other reasons, the CEO believed CSR-related environmental efforts and Formula 1 did not fit well together. On a product level, "greening" increasingly has expanded across the lifecycle, to include six Rs: repair-extend the life of a product by repairing its parts; recondition-extend the life of a product by overhauling it significantly; remanufacture-create a new product based on old ones; reuse-design a product for multiple uses; recycle-reprocess and convert products into raw material to be used in another or the same product; and reduce-ensure the product 
uses less raw material or generates less disposable waste even as it delivers comparable benefits. ${ }^{2}$

Multiple conceptualizations of CSR exist, and a single definition has yet to be accepted. For the purposes of this article, we subscribe to the view that CSR is about companies going beyond legal obligations and their own interests to address and manage the impact their activities have on society and the environment. ${ }^{3}$ This view therefore includes how companies and their managers interact with stakeholders-those "persons or groups that have, or claim, ownership, rights, or interests in a corporation and its activities, past, present, or future" ${ }^{4}$ including customers, suppliers, employees, investors, and the communities in which they operate, as well as the degree to which they endeavor to care for the natural environment.

Despite its current popularity though, the use of CSR-based brand management can be a dangerous endeavor. Stakeholders have varying expectations regarding CSR activities, and when claims of CSR as a guiding value system turn out to be window dressing, customers and consumer groups put violators on trial in the court of popular opinion. ${ }^{5}$ Companies often try to develop a CSR brand, such that the brand becomes "a dynamic, vital, living entity, fed by the interaction among its myriad stakeholders, ${ }^{\prime 6}$ but doing so means conventional approaches to brand management invariably fall short.

A traditional brand strategy focuses on primary stakeholders (e.g., customers, shareholders, business partners), without whom the company cannot produce and sell goods or services. In contrast, because a good corporate citizen is expected to address the concerns and satisfy the expectations of individuals and groups who can affect or be affected by the company's activities, but who are not formally engaged in transactions with the company, developing a meaningful CSR brand demands the consideration of secondary stakeholders. ${ }^{7}$ These stakeholders include social and political actors who support the company's mission by providing tacit approval of its activities. From a more instrumental viewpoint, they can help provide intangible assets to the company, such as reputational, capability-related, and knowledge-based resources. Thus from a brand strategy perspective, a CSR positioning must be based on an overall brand value or theme that connects with all relevant stakeholder groups. ${ }^{8}$ Good relations with primary stakeholders of course remain central guideposts for companies as they develop their intangible assets, but the development of relevant, successful CSR branding initiatives also "depends explicitly on the promises the brand has filtered to each stakeholder, and implicitly on the trust that the brand's reputation has accumulated with all stakeholders," including secondary ones. ${ }^{9}$

Because the rules of the branding game are different, we know that we need new insights into how to manage CSR-related issues. Unfortunately, most existing approaches simply recommend that the business and brand strategy should be aligned with CSR activities, or they focus on specific elements, such 
as the financial impact of engaging with CSR activities. ${ }^{10}$ In general though, practitioners remain in a state of confusion when it comes to deciding how to tackle CSR in a way that benefits both the company and society at large.

Building upon multiple case studies, we examine corporate social responsibility and corporate branding-in particular, the issue of how to leverage strategically corporate social responsibility to the benefit of company and society. Our findings add value to the extant literature on not only corporate social responsibility, but also-via its theoretical lenses-ethical identity and corporate branding. For an introduction to the latter literature, we refer to the International Corporate Identity Group (ICIG) symposia and proceedings.

\section{Branding at the Product vs. Corporate Levels}

The rise of CSR over the past two decades-in both theory and practicehas coincided with the advancement of marketing at the institutional level, that is, "corporate marketing." ${ }^{11}$ For the purposes of our study, corporate marketing is defined as "a customer, stakeholder, societal, and CSR/Ethical focused philosophy enacted via an organizational-wide philosophy and orientation." ${ }^{12}$ This view of corporate marketing, which is "informed by identity-based views of the firm,"13 integrates various notions about corporate-wide marketing that have attracted the interest of scholars and practitioners since the 1950s-such as corporate identity, corporate branding, corporate communications, and corporate reputation-into a distinctive marketing model in its own right ${ }^{14}$ and which provides "distinctive platforms from which multi-lateral, organizational, and stakeholder/societal relationships are fostered to all-round advantage."15

At the heart of the shift toward corporate marketing, the overall move from the product brand to the corporate brand is well documented in marketing literature and largely has been attributed to the influence of product commoditization and globalization. ${ }^{16}$ The corporate brand notion relates to "the visual, verbal, and behavioral expression of an organization's unique business model." ${ }^{17}$ In contrast with product brands, which primarily appeal to customers, corporate brands speak to multiple and diverse audiences, including customers, employees, shareholders, the financial community, media, NGOs, and so forth. The corporate brand, which applies a single brand across the entire company, must appeal simultaneously to these diverse stakeholder groups. The core of the corporate brand must represent “an explicit covenant between an organization and its key stakeholder groups." ${ }^{18}$

In essence, a product brand can be defined by what it does and represents, whereas a corporate brand also is determined by who it is. Next to its business model, a corporate brand is linked intrinsically to the identity of the company; thus it encompasses the distinct attributes and values of the company to define for what the company stands ${ }^{19}$ and relates "to what is promised and expected in identity terms." 20

In a similar sense, Hatch and Schultz hold that "if corporate branding is going to be more than romanticism about the organization's future, the claimed values of the corporate brand must resonate with the tacit meanings and values 
that organizational members hold and use." ${ }^{21}$ That is, corporate branding must build on the company's current culture, which reflects its identity. By doing so, Keller and Richey contend, corporate brands can "establish a number of valuable associations in the minds of customers and other key constituents that can help to differentiate the brand, such as common product attributes, benefits, or attitudes; people and relationships; programs and values; and corporate credibility."22

However, the management of corporate brands is a complex process. A corporate brand should carry attributes and values that help the company differentiate itself from competitors, assuming those attributes and values are congruent with the company's specific corporate identity, ${ }^{23}$ which here is understood as the "summation of those tangible and intangible elements which make any corporate entity distinct." ${ }^{24}$ These distinct elements must provide "the grit around which a corporate brand is formed." 25 For example, the Swiss company Nestlé promises "Good Food, Good Life" and sees its identity as based on ideas of fairness, honesty, and a general concern for people. To develop a consistent and coherent brand image, Nestlé must make these attributes and values explicit to its stakeholders, who will then ascribe meanings to the company-ideally ones congruent with the company's corporate identity—as a result of their brand experiences. ${ }^{26}$

In many cases however, the actual attributes and values of a company (i.e., its actual identity) may contrast with the messages included in the company's communications (i.e., the communicated identity) and with the perception(s) that the company's stakeholders hold, that is, the company's corporate image and reputation (i.e., its conceived identity). Companies therefore must manage multiple identities to avoid potentially harmful misalignments. ${ }^{27}$ They have to advance attributes and values in a coherent way so that stakeholders hold a relatively similar overall perception of the company's identity, which again helps ensure that stakeholders perceive the companies as having integrity and credibility. We need to distinguish between the actual identity of a company on the one hand and the perceived brand image on the other. Although it overlaps with the notion of a corporate brand, corporate identity differs; it is utterly necessary, whereas a corporate brand is contingent on the promise offered to the company's stakeholders. ${ }^{28}$

Furthermore, corporate branding involves most of the company, including employees, in brand delivery, which means marketing by itself generally cannot align all necessary processes, systems, and structures with the corporate brand. Ultimately, the corporate brand becomes a strategic issue, worthy of the CEO's attention. Ideally, the CEO places brand concerns on the company's strategic agenda, moving them beyond short-time projects. In contrast, the ongoing focus on product brands often limits brand meaning and definition to the marketing department.

\section{The Challenges of Using CSR for Branding}

Because functional sources of product differentiation (e.g., green functions, processes, systems) are easy to imitate, questions arise about whether CSR really can offer long-term, sustainable differentiation at the product level. Some product classes have turned to CSR-based emotional benefits. Consider, for example, 
Yoplait's "Save Lids to Save Lives" initiative, which associates 10 Yoplait products with the Susan G. Komen for the Cure foundation, the largest breast cancer organization in the United States. In its cause-related marketing campaign, first launched in 1999, Yoplait produces containers of yogurt with special pink lids that consumers can submit to the company, prompting Yoplait to donate 10 cents per lid. By refining this initiative over time, supporting it with media exposure, and encouraging women to engage proactively in local campaigns, Yoplait has ensured its products and brands link closely to a cause with benefits for both society and the company. Yoplait taps into consumers' affections and emotions: It has taken "something as small as a yogurt lid and turned it into inspiration and hope." ${ }^{29}$ Furthermore, the initiative enables Yoplait to differentiate its products and brands and build emotional bonds with consumers. ${ }^{30}$ Yet even this route is becoming more challenging as consumers grow increasingly sensitive to the potential for emotional manipulation. Companies thus keep searching for new sources of differentiation, and many have started to develop corporate CSR brands-often without ever evaluating the actual implications of such a strategy.

When companies proclaim their embrace of values that relate to CSR, they immediately come under increased scrutiny and often attract the attention of activists and interest groups that aim explicitly to counter their marketing efforts. Marketing in general, and branding in particular, can invoke deep mistrust, often brought on by companies when they offer empty promises, exaggerated claims, and inaccurate information. ${ }^{31}$ Suspicious consumers are more alert and more aware, even as, ironically, corporate brands become more transparent through greater communication among employees, customers, and other stakeholders. As a result, incongruity may arise among the actual CSR-related attributes and values of the company (i.e., actual identity), what is communicated about the company's CSR initiatives (i.e., communicated identity), and how its stakeholders perceive the CSR commitments, initiatives, and CSR messages of the company (i.e., conceived identity). In such cases, there is a risk that the company will be accused of hypocrisy and deceiving the public. $^{32}$

Toyota received a reputation for environmental responsibility by introducing its celebrated hybrid, the Prius. However, even as Toyota enjoyed phenomenal awareness levels and positive associations, in addition to sales bumps, it suffered from increased attention to its corporate actions. Loyal Prius owners, special interest groups, and NGOs vigorously challenged Toyota's lobbying efforts (in cooperation with Ford and General Motors) against tougher U.S. fuel economy standards. These conflicting messages-namely, advertising that claimed "harmony between man, nature, and machine" together with corporate actions that seemingly harmed the environment-undermined both the corporate brand and the product brands. ${ }^{33}$

In the modern economy, the terms "CSR" and "sustainability" have become such buzzwords that companies seem to believe they must embrace CSR, without ever taking the time to evaluate their options. Rather than take a strategic approach to CSR, they make it a key driver of all corporate actions-often unnecessarily. Moreover, a focus on CSR is no simple panacea; it invariably initiates a conversation with wider society, beyond immediate stakeholders, which may not be a conversation the company wants to have. ${ }^{34}$ To avoid misalignments across multiple CSR-related 
identities and dodge the potential backlash of CSR branding, strategies at the corporate level require a strong and authentic commitment from the organization. First, companies must engage in the difficult task of carefully assessing their actual identity. It is necessary for them "to examine the actual heterogeneous characteristics of their organization, such as the organizational structure, the leadership style, and the multiple sets of shared values held by management and employees." 35 Only on such a solid basis can the company then devise the appropriate balance of CSR, strategy, and brand management that can produce a competitive advantage for the company.

Second, once they have engaged in CSR-related branding at the corporate level, companies face unyielding pressure to measure the financial impacts of this engagement. However, there is no universal, normative standard for societal involvement. If management must deliver bottom-line results, CSR can become an ethical dead end. ${ }^{36}$ Perhaps then the company should be redefined as a politicized actor that maneuvers discursively between civil society and the state, while also earning profits. ${ }^{37}$ In this case, the company is an economic and a political actor in all market societies.

Third, if we accept this premise, another key challenge becomes manifest, namely, balancing the various expectations of stakeholders. Using a CSR positioning typically entails a "significant strategic shift in the way the organization thinks about itself and its activities, including communications with [a wider range of] internal and external stakeholders." ${ }^{38}$ In a global context, stakeholders from different cultures and various geographical areas want strategic consideration, and powerful secondary stakeholder groups demand a voice, if not a seat at the corporate table. These stakeholders' expectations are not only inconsistent, but also likely shift over time and space. ${ }^{39}$ As they grow more active, the company faces an increasing need to deal with stakeholders' demands discursively. The pluralism of global cultures and values means there is no ultimate frame of reference, no ultimate truth, no universal knowledge, and no universal business ethics. Even honest, sincere brand-related stories can induce both positive and negative public discussion that might alter and perhaps damage the way consumers and other stakeholders perceive the brand.

Accordingly, this article summarizes some approaches that companies apply to develop their CSR brands, derived from multiple case study results. On the basis of these findings, we propose an integrated framework that helps us understand how companies position their corporate brand in terms of CSR, as well as managerial recommendations for how companies can retain consistency in their brand promise, despite the divergent expectations of their various stakeholder groups.

\section{Methodology}

Qualitative methods are appropriate for studies of complex processes, ${ }^{40}$ so for this investigation of the complex concepts of CSR and branding strategy development, we chose a multiple case study approach. We identified nine globally operating companies as relevant because of their varying involvement with CSR topics, as the details in Table 1 describe. 


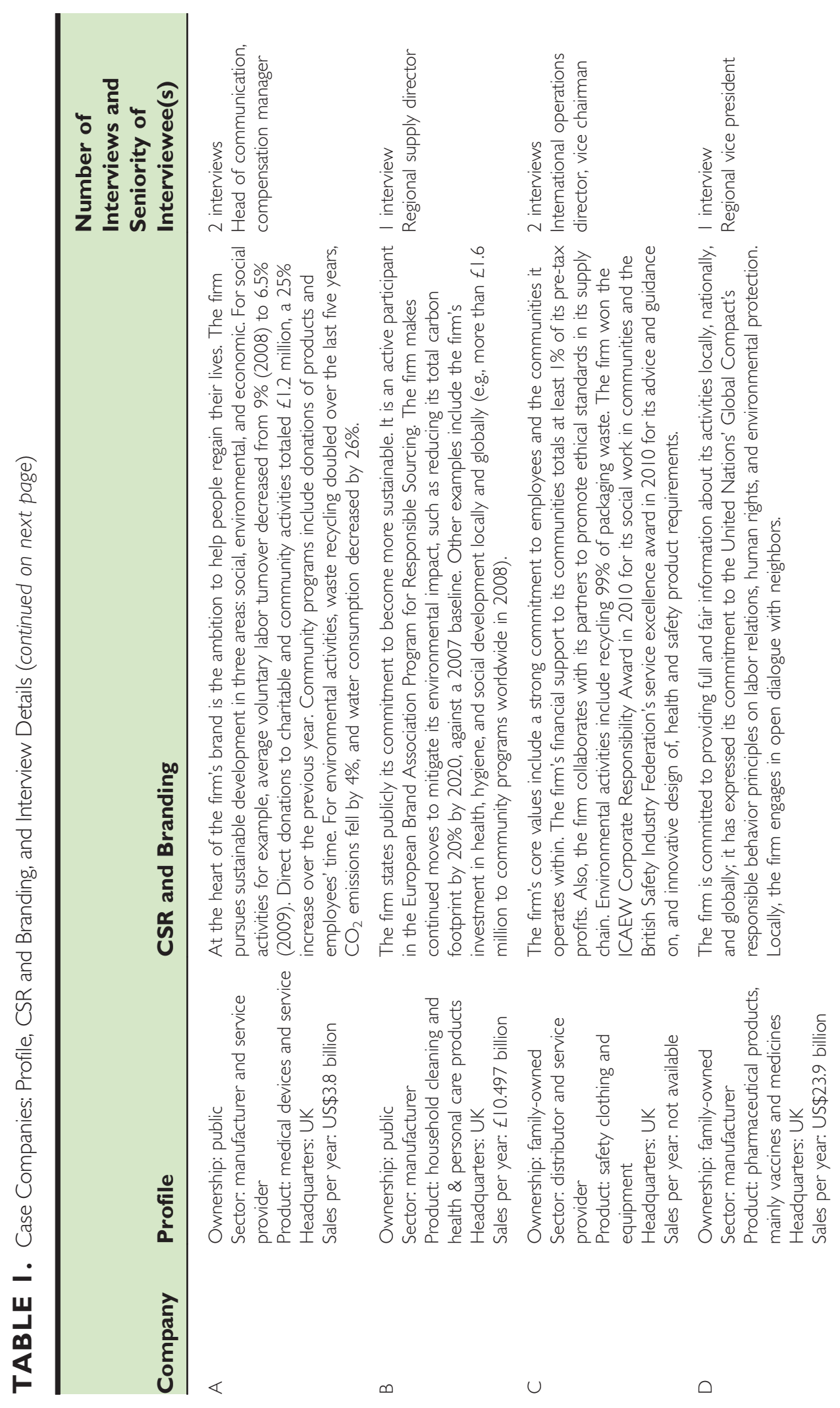




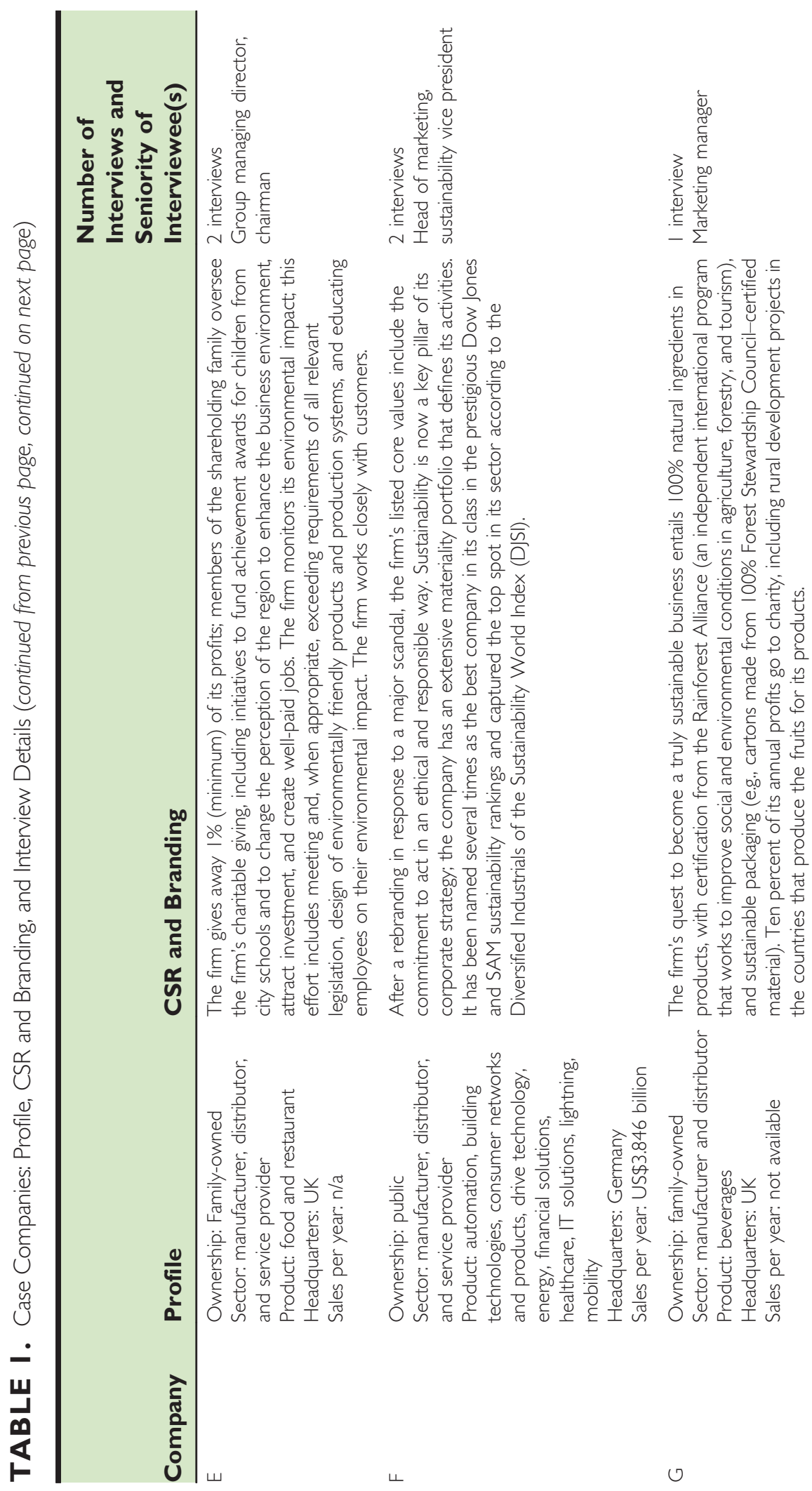




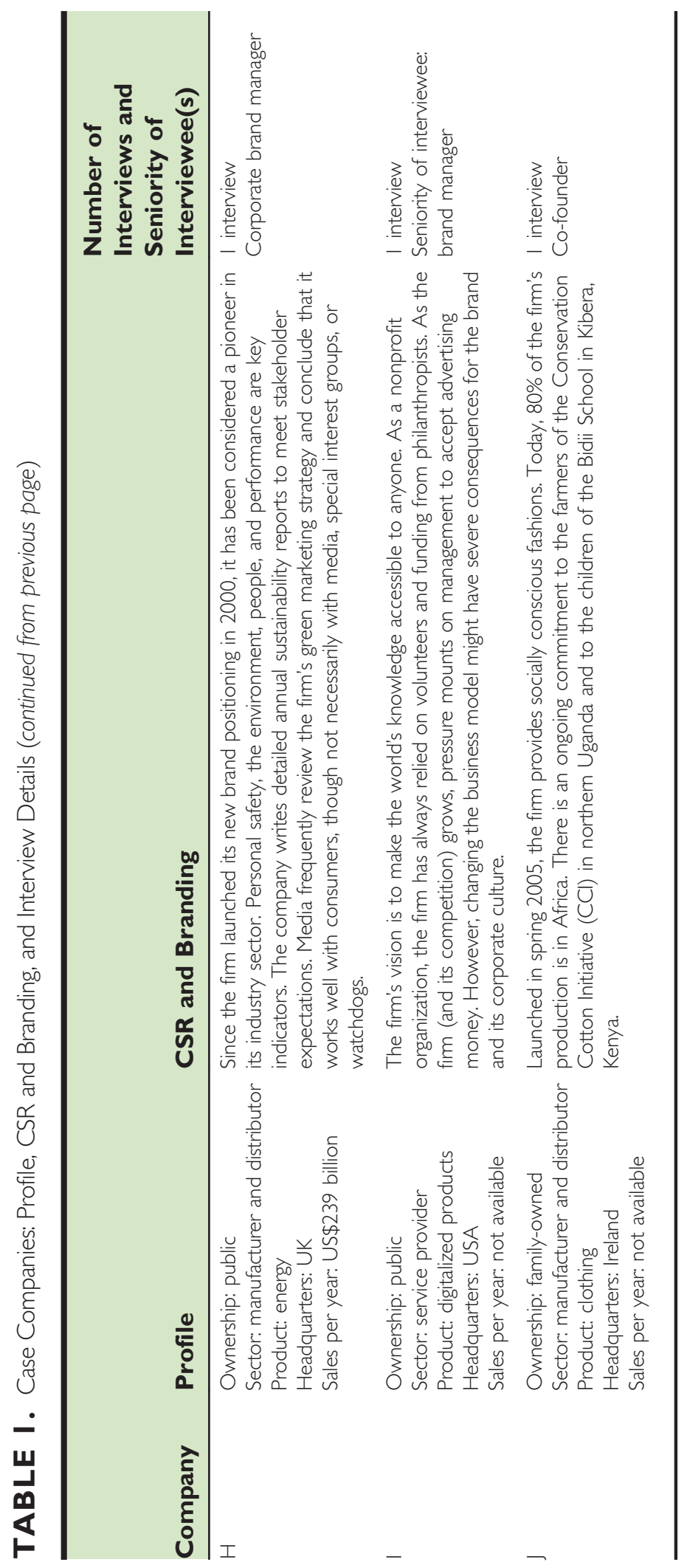


Through our data collection, we attempted to gain an in-depth understanding of these companies' approaches to CSR; the reasons and main objectives for their engagement in CSR activities; and the associated pressures, levels of success, and determinant factors. Therefore, we conducted in-depth interviews, mostly with brand managers and members of the brand team, after we had collected publicly available secondary data and promotional information about each company.

The interviews began with broad, "grand tour" questions that enabled the informants to present the material in their own terms. Specific prompts helped induce greater insights into specific lines of inquiry, such as details about particular programs. Although we used a short, standardized interview guide to drive the interviews, the process included topics as they emerged from each interview and acknowledged the unique aspects of each case. On the basis of a brand leadership framework, we formed a general question pertaining to each main dimension: brand positioning, brand architecture, the development of CSR initiatives and their degree of integration in the strategy and the culture of the company, and the CSR-related brand strategy of the company. ${ }^{41}$ Figure 1 depicts the overall data gathering and analysis process.

For our case analysis, ${ }^{42}$ we pursued a rich understanding of the processes that each company underwent to engage in its chosen CSR activities and brand management. To ensure we obtained a holistic, contextualized recognition of how marketers approach CSR and branding, we tacked back and forward between previous literature and our data, which helped us develop several theoretical categories. ${ }^{43}$

\section{CSR Brand-Building Processes}

From our case studies, we identify four main ways that companies link CSR to their brand-building efforts, whether directly or indirectly. First, companies respond to different initiators and drivers when they choose to engage with

FIGURE I. Data Gathering Process and Analysis

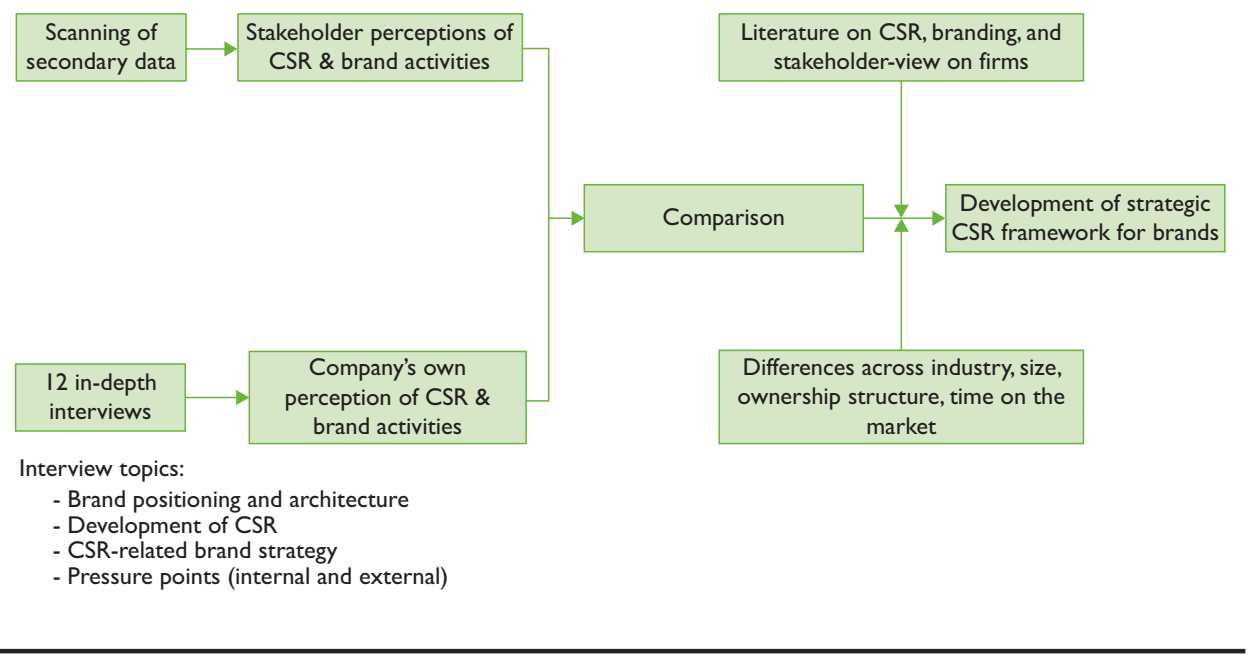


CSR. Second, they want to achieve diverse objectives. Third, companies exhibit variety in the extent to which they integrate CSR activities into their brand identity. Fourth, they measure the outcomes of their efforts in various ways.

\section{Initiators and Drivers}

Two main types of triggers drive awareness of CSR as a brand tactic: marketbased, stakeholder-led factors (such that companies anticipate or respond to key stakeholder expectations and market needs) and values-based, management-led factors (usually resulting from the aspirations and efforts of individuals or groups within the company).

On the one hand, the market-based triggers were particularly pertinent for the publicly owned companies in our sample. For example, faced with increased market competition, company B entered into a merger; as a result, the company's managers came to realize that to maintain brand value, they needed to find a new means of establishing it. They pursued their CSR initiatives to increase employees' engagement and to reduce the negative impacts of the merger on how external stakeholders perceive the value offered by the brand. For example, they provided full disclosure about the merger, which helped reduce anxiety among employees and external stakeholders. Their disclosure also provided the company with an opportunity to differentiate its brand according to its CSR initiatives.

On the other hand, CSR initiatives induced by values-based factors appeared particularly, though not exclusively, relevant to family-owned companies. For example, at company $\mathrm{C}$, a fourth-generation family member gained external working experience and thus realized a need for change in the company's way of conceiving, addressing, and demonstrating its social responsibilities. Upon his return to the family business, he argued that the company should engage in CSR-related initiatives for ethical, values-based reasons-rather than just reputational concerns-that more consistently and visibly reflected the inner beliefs and ideals managers held as individuals and that he believed characterized the management team and organization. At company J, managers collectively embraced the company's founding principle, "trade, not aid," to build sustainable communities in underdeveloped countries and hired skilled workers who could create fashionable clothing. These CSR-related branding initiatives truly reflected the value-based ideology underpinning the activity of the company:

We've got some ... core values and it's all about just doing things right, and doing things for the right reasons. It wasn't created as some kind of mission statement or grand marketing exercise. It is just a core belief that cascades down from the people that own the business to the people who manage, operate, and work in it.

Finally, our findings suggest that values-based triggers often align with market-based triggers. Company D brought in an outside CEO who had previously succeeded in developing a CSR brand for another company. This CEO started his tenure by understanding how CSR was conceived and translated into practice in every division, quantifying the value of CSR for every division of the company and highlighting the potential for brand value using a market-based perspective. Similarly, at company $\mathrm{H}$, a manager recalled that values-based motivations and 
stakeholder-oriented objectives (from employees in this case) combined to trigger the development of CSR-related branding initiatives:

In 1999, we had just begun a series of acquisitions, adding thousands of employees to the company who shared no common past but a common future. Therefore, we were looking for a platform of values that could create a shared purpose that would equally excite and motivate all employees.

\section{Objectives}

Companies, according to our findings, engage in CSR and CSR branding either to generate or to protect value. Value generation includes both economic and social value, such that the value of CSR directly or indirectly affects the processes for developing brand value. When we asked respondents explicitly about what their companies had hoped to achieve through CSR, they all mentioned strengthening corporate values, corporate mission, and business strategy. For some companies, such as J, the link between CSR and the brand was very natural, as the company's historic focus has been to generate not only economic benefits for the company, but also positive impacts on the communities in which it operates:

Our brand vision is to become synonymous with beautiful clothes made in Africa. We really want to prove to the world that Africa is a modern place and that it can be done. We take pride in the beauty and quality of our clothes and do not want them to be a pity-purchase. However, it will be a lot of work before "Made in Africa" will take on this meaning and it can be quite challenging at times.

Such broad objectives for value generation should be transparent to every employee. Therefore, company G formally designated five key values: "Be Natural, Be Entrepreneurial, Be Generous, Be Commercial, and Be Responsible." In weekly meetings and retreats, as well as informal gatherings (e.g., picnics), employees debated their cultural values to confirm the company's core value themes. They also identified and detailed the subtleties of what elements should be part of their CSR agenda. Such organic development emphasizes a bottomup, employee-based approach. In this sense, the value originally designed to come from CSR initiatives actually may result from greater awareness, buy-in, and involvement among employees, as well as collaboration with other stakeholders. In company E, employees felt more engaged because of the sense of integrity they gained from the interaction between their corporate brand and CSR:

We take corporate social responsibility seriously because we believe it is the right thing to do. What we are seeking to do with the firm is a sort of a recruitment brand. We're directly speaking to people who are either working with us or who might consider working with us to say, "Look, we do this sort of thing because we care." We're not telling our customers and we're not telling our consumers. It is a private thing. It's something we do because it is right. We're not doing it because we want someone to say: "Well done!"

We found that public companies in particular sought to generate economic and social value through CSR:

We have integrity and an ethical approach to business. Once we set clear values, we check every activity we have been involved in or every initiative we are going to 
launch. When a new initiative is considered, we ask the following questions: Will the initiative add value for caring for people's health and help us to deliver better performance? If not, we won't do it. Will the initiative add value to the innovation of our product and services? If not, we won't do it. Will the initiative add value for building trust with different stakeholders including customers, suppliers, communities, etcetera?

Value protection instead focuses more specifically on economic value and is oriented toward ensuring the company's license to operate in the shorter term. We found that all the case study companies considered the local community central. Value protection becomes especially relevant if a company's reputation is threatened by a scandal. Consider company F. It experienced enormous pressure to focus on compliance-related processes and standards and thus demonstrate that it had eradicated the root cause of its misbehavior and noncompliance. The people in charge of "cleaning up" received a mandate and authority to interfere with business practices and processes; however, this mandate increased bureaucracy and inefficiencies. Compliance efforts nearly overpowered everything the company did-perhaps because the new code of conduct was designed without the involvement of marketing or branding teams. In this case, communicating to stakeholders through appropriate channels about the measures taken to solve CSR-related issues provided key elements to ensure the company's credibility and reputation.

\section{Level of Integration}

Two levels of integration emerged from our study: CSR as ingrained and CSR as an add-on. Some companies consider CSR part of their corporate culture and strategy, including brand values. In other cases however, CSR never gets ingrained into the companies' cultural and strategic fabrics and essentially remains peripheral, an add-on to be communicated about when needed. Several of the studied case companies realized the benefits of CSR only after they communicated their engagement in CSR to customers. When company C found new suppliers, it audited them according to its CSR standard, which helped protect the brand and avoid reputation damages. Yet its CSR committee did not explicitly consider branding. If the company needed to make decisions about CSR or branding:

[B] randing is not a feature that will be considered by the CSR committee. So they are not linked. [Interviewer: So, CSR is one thing and branding is another?] That is right. We tend to look at those in their own rights, as valuable additions to the community, but not as competing, not as to what each CSR initiative would add value to the brand. The brand is so indefinite that it is not part of the decision-making process. We just accept if we've got enough, it will benefit the brand.

In a similar way, though company D recognized its CSR brand strategy was more relevant to its corporate brand than to its product brands, from a consumer perspective, it perceived no obvious link between CSR and brand value:

The link [between CSR and brand] is not necessarily taking place, certainly not in my business such as the consumer department, nor in most of the other businesses. . . . If you are doing CSR, people think that's a good firm and it is worth investing in it 
because they are obviously doing all the right things. However, it is very difficult then to associate these right things with the brand because nobody links these two, very rarely do they link the two.

For company E, the brand/CSR link emerged only in the limited context of building a corporate image, though integrating CSR and brand value offered twosided stakeholder-related benefits: better recruiting and retention of talented employees and strong relationships with business partners. As a manager described:

To me, CSR may sit around branding or marketing. But it isn't necessarily. I don't think our approach to CSR shapes the way that we think about the brand. CSR does say something about the sort of firm you are. I think you can see the linkage from our attracting and keeping young and talented people. I think it can distinguish you from other firms. In that respect, CSR is building a sort of employment brand, which means people know your name and believe it is an honest and a good place to work for. If we are buying a business, I absolutely think and absolutely know that a fellow would see us as being a better home for their business.

Although none of these privately owned companies suggested they developed a CSR brand strategy, some managers acknowledged that in certain circumstances it was more appropriate to create a CSR brand. For example, in business-to-business markets, CSR strengthens the commercial value of its company by helping it identify business partners that share similar values or differentiating it in the global marketplace.

In other cases, companies actively sought to integrate CSR into their culture and strategies. Such integration does not need to be comprehensive but rather can focus on several key areas. Therefore, company B linked its CSR to its brand by focusing on an environmental dimension, because for the household cleaning materials it sold, conformity with environmental expectations and norms was crucial. It also determined CSR initiatives to pursue according to different global markets:

I guess it depends on markets. So I think not so much in the UK but you see in some, particularly the developing world, there are lots of programs where the brand is associated with some improvement in the community. So, particularly in India, you would see a lot of things where they have worked on clean water systems, improving water supplies, and those are definitely linked with the brand.

For companies that attach strategic importance to CSR and branding, close working relationships with other departments also are necessary. Thus company G explicitly related its CSR management to its consideration of its employees as key assets and involved its human resources department. Repeatedly ranked as a "best place to work," it offered a key comparison:

Like our products, our brand is $100 \%$ natural. Our brand is not manufactured, it is lived. From the very beginning, [company G] was about producing tasty drinks that are healthy for people, working with nice people and doing good. It really shows, you can feel it if you work here. We have a lovely, unique brand that we are all extremely proud of.

The company remained very cognizant of employees as pivotal to its success and brand delivery; its stringent recruitment process could take up to six months. 
However, employees eventually benefited from a working environment based on praise and support, ongoing training, and education, in which the human resources department relied on input from experts in socially responsible practices. Through such processes, CSR-related values percolated through organizational and individual levels, thus ensuring that CSR was ingrained into the culture of the company. That culture in turn shaped the context within which the company defines and implements its orientations and policies, including branding strategies. ${ }^{44}$

\section{Measurement}

Measuring the performance of the CSR brand remains a constant challenge. Some companies call it impossible, which inevitably means they cannot determine whether CSR enhances brand value. A manager of company C argued that the only important measurement was whether the company was still in business, surviving and earning profits. If the company could still hire employees who worked hard and happily, its practices must be succeeding.

However, most companies, when they form clear CSR brand strategies, also tend to adopt multiple tools to measure, sustain, and improve their achievements. Some publicly owned businesses used performance-related measures, though their implementations differed markedly. For example, company F defined goals, target dates, and status for each of its various business sections. In the area of occupational health and safety management goals, one aim was to reduce the number of work accidents to less than 5 per 1,000 employees. In September 2010, the company reached this goal, and it currently suffers only 4.3 work accidents per 1,000 employees. Other companies also use annual CSR or sustainability reports, surveys, or third-party assessments as measures. The sustainability report for company $\mathrm{H}$, for example, is audited by an external consultant.

\section{Developing a Strategic Approach to CSR}

Our findings suggest a somewhat controversial claim: CSR leadership makes sense only for some companies, not all. That is, the appropriateness of CSR, from a strategic standpoint, depends on the nature of the industry, the nature of the product offering, and the corporate culture and ethos. ${ }^{45}$ Within the framework of business and brand strategy, CSR requires strategic alternatives that the company can assess according to their impact, risks, and benefits, then measure with regard to their progress and impact. Companies that address CSR strategically thus can leverage CSR to benefit both the company and society, whether as: CSR entrepreneurs, CSR performers, vocal CSR converts, or quietly conscientious. We define these categories according to the objectives, level of integration, and key initiator and drivers of the CSR brand-building activities. We leave aside the CSR measurement dimension because it constitutes a consequence of the company's strategic position rather than a key determinant or feature. In addition, we contend that the level of corporate involvement in CSR-or the degree to which companies respond reactively to demands for CSR or engage proactively in 
FIGURE 2. Strategic CSR Brand Framework

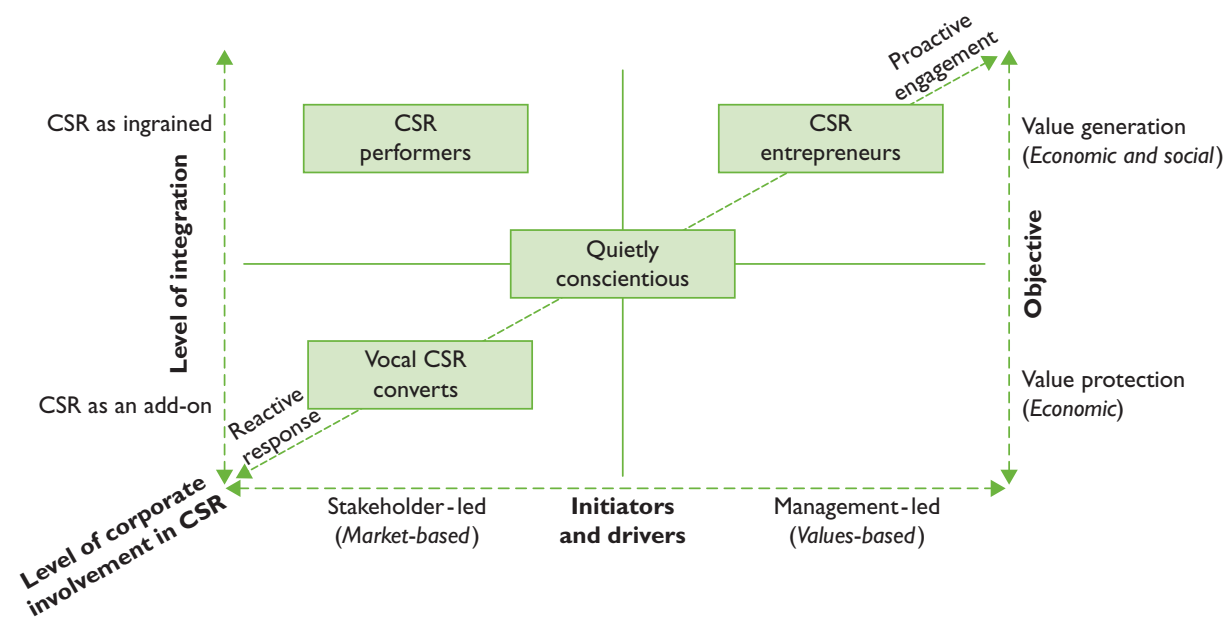

CSR initiatives-constitutes a transversal dimension in our strategic CSR brand framework, as Figure 2 illustrates.

\section{CSR Entrepreneurs}

When companies design their corporate identity around CSR, because they have been founded with CSR in mind and embrace CSR as part of who they are and what they do, they are CSR entrepreneurs. ${ }^{46}$ Their ethos often reflects the passion, vision, and personality of their founders. Thus, their form of CSR goes beyond supportive systems and structures to include their overall identity and outlook. ${ }^{47}$ CSR is ingrained in their history and culture. Consider companies such as the California-based Patagonia. Its strong support of environmental preservation forms a constituent part of its corporate soul and brand, and it has ever since Yvon Chouinard founded the company in the early 1970s. Devising great products that cause the least possible environmental harm and using business to inspire and implement solutions to the environmental crisis are still at the heart of the company's value proposition. ${ }^{48}$ Another example of a CSR entrepreneur is GLS, the first social and ecological bank in Germany. The bank's corporate brand values include sense, profit, and security-all of which are rooted in the history of the anthroposophical activities of the lawyer Ernst Barkhoff, who pursued a new social and economic society. These values emerge in the form of the company's focus on cultural, social, and ecological projects that attempt to tackle challenges to society with creative solutions. Loans go to projects such as independent schools and kindergartens, organic farms, therapeutic teaching institutions, nursing homes, employment projects, health food stores, and communal living projects. By making transparency 
another of its key aims, GLS has attracted many customers who prefer reduced interest payments on their savings if they can be assured that those funds will support responsible investments.

Many proactive CSR entrepreneurs engage in commercial activities to pursue nonprofit objectives. Commercial intentions move backstage as the company works to reinforce the authenticity of its noncommercial brand as sincere and authentic. $^{49}$ Often, noncommercial motives represent the moral imperative of the corporate brand.

Yet every decision these companies make requires the consideration of two, possibly conflicting criteria: What is the greatest possible benefit to the company, and what is the greatest possible benefit to society? Our interview respondents asserted that being socially responsible does not by definition contrast with shareholder interests; in many cases, it can enhance shareholder returns. The objectives of these companies and their corporate brands therefore encompass the generation of both social and business value. As is evident from our interview with company $\mathrm{G}$ though, this chosen path requires determination:

If the founders had taken our company public, we would probably no longer exist in this form. Stockholders would have never had the patience for us to grow our business whilst remaining absolutely true to our brand promise. Time has proven us right, but it took a lot of courage, persistence and determination.

Our research also suggests that CSR entrepreneurs tend to be smaller and younger. Because they have not (yet) accumulated the baggage of being large and global, they can work from a clean slate. Nevertheless, examples of more traditional companies following the CSR entrepreneurship path have arisen in the past two decades. For example, Ray Anderson, the founder and former CEO of Interface, a leading manufacturer of carpet and fabrics, has engaged in a transformational change challenge. Anderson experienced an epiphany in the mid-1990s when he read Paul Hawken's The Ecology of Commerce, which prompted him to radically redefine Interface's purpose. The objective now is to be an exemplar of the move toward a sustainable and restorative enterprise in five dimensions: people, place (the planet), product, process, and profits. ${ }^{50}$ This management-led challenge pushed the company to create new ways of seeing, believing, and doing that reflected its deep values and assumptions. These substantive changes to the corporate identity are reflected in the company's corporate brand positioning. ${ }^{51}$ In 2006, for example, Interface publicly announced its "Mission Zero" program to eliminate its negative impact on the environment by 2020 .

Beyond these emblematic examples, ${ }^{52}$ the increasing popularity of sustainability also attracts pretenders that hope nobody checks their claims of being "organic," "natural," or "sweatshop free." True CSR entrepreneurs thus need a strict code of ethics, along with authentic leaders who adhere to norms and monitor the supply and value chains. ${ }^{53}$ Violations of defined standards, especially with regard to no-tolerance issues such as child labor or physical violence, demand immediate responses. Therefore, CSR entrepreneurs must develop strong partnerships with their stakeholders and partners throughout the supply chain. 


\section{CSR Performers}

The CSR performers normally are established, highly visible brands, with core environmental and social responsibility values, as well as the scale and ambition to transform their industries. Although CSR principles are ingrained in their organizational culture, in many cases they engage in CSR activities not for values-based, internal reasons but rather in response to stakeholder expectations. Although their sense of CSR may come from within, these usually publicly owned companies must adopt a shorter-term view, based on a clear goal: to design a CSR agenda and integrate their CSR and branding activities to earn profits for shareholders. Managers of these highly visible CSR performers, such as the U.S. giants Starbucks or Timberland, face pressures associated with accountability, limited resources, and public governance; they also make more direct comparisons of the value of investing in CSR than do managers of privately owned companies. ${ }^{54}$

Some companies try to build a sense of internal ownership of CSR-related brand programs by aligning their incentive, training, and hiring policies with this desired positioning; providing ongoing communications about the brand/CSR link; and developing systems to ensure consistent delivery and integrate CSR in the company's culture to at least some degree. However, many of these companies act only half-heartedly; BP's brand crashed in 2010 when its spewing oil well (and failure to cap it) undermined its promise of "going beyond petroleum." 55

Yet shared CSR convictions also can help companies survive tumultuous events. The beauty and wellness brand Aveda was founded in 1978 "with the goal of providing . . . high performance, botanically based products that would be better for service providers and their guests, as well as for the planet,"56 and it has since gained a reputation as a leader in sustainability efforts. Then its founder left and the company was purchased by Estée Lauder in 1997, after which it experienced rapidly increasing sales and a tripling of its workforce. The company was able to retain its brand image and reputation, though, because it remained consistently dedicated to sustainability as part of its culture, not as a marketing position.

Finally, just as CSR entrepreneurs might be publicly owned companies (e.g., Interface), CSR performers include privately owned companies with strong and visible corporate brands in industries that are scrutinized by powerful secondary stakeholders. Consider IKEA. Its business vision, “[to] create a better everyday life for the many people," supports the company's ambition of integrating social and environmental considerations into its daily operations and placing such considerations at the heart of its corporate brand. Rooted in a Nordic business philosophy that tends to think of ethical values, politics, and economics as constituents of a virtuous circle, IKEA believes it can reduce the conflict between CSR and profit functions. ${ }^{57}$ However, IKEA's emphasis on cost effectiveness and its engagement in emerging and developing countries sometimes has conflicted with the company's ambition to be regarded as a responsible corporate citizen. The company thus occasionally is the target of criticisms that have contributed to pushing the stakeholder-led CSR agenda of IKEA. Through a mix of reactive actions to stakeholder criticisms and proactive initiatives, often developed in collaboration with stakeholder groups such as the World Wildlife Foundation or UNICEF, IKEA 
has secured a strong brand position, such that the brand is perceived as a guarantee of environmental consideration and social responsibility.

\section{Vocal CSR Converts}

Other large global brands recently started to embrace CSR, in reaction to a growing CSR imperative. Unlike CSR performers, they have not convinced the public that their efforts are genuine or long-term, but this list of companies continues to grow as more global brands work to integrate CSR into their business and brand strategy. ${ }^{58}$ Whether they must overcome legacy issues or consumer cynicism associated with CSR being perceived as a mere add-on to a brand proposition, such large companies often prompt retaliation when they shift their communications to embrace CSR issues-as evidenced by General Electric's (GE) Ecomagination campaign. According to Vice President of Ecomagination Lorraine Bolsinger, the company anticipated tougher environmental standards, scarce resources, and growth and therefore wanted to reconsider sustainability, an effort that would benefit GE while also helping the environment. ${ }^{59}$ Ecomagination was designed to incorporate such values into all its energy-related businesses, but as Bolsinger readily admits, "Ecomagination was never based on 'we're doing this for philanthropy' or 'we're doing this to make the world safe.' We're glad to be doing that as a result of making money. It's a different lens that informs your decisions about where to spend money and what resources you're going to invest. ... Ecomagination is for us, above everything else, a growth strategy." ${ }^{60}$ In response, critics - who became vividly aware of the company's sustainability claims through GE's communications blitz-have charged that not only is Ecomagination a cynical attempt to exploit interest in the environment, but it also does not set sufficiently ambitious targets for "green" products. For vocal CSR converts, the typically reactive and pragmatic approach to doing what is good for business and a dominant emphasis on communication around peripheral CSR initiatives may not be sufficient to create brand value and overcome a legacy of irresponsibility in a context of generally increasing stakeholder expectations and scrutiny.

In turn, some vocal CSR converts choose to identify specific causes that are relevant to certain strategic products of their business. This practice exemplifies our finding that specific markets create unique dynamics that determine the development of CSR brands. Our Toyota example shows that CSR on a product level (Toyota Prius) provides the entire company, as well as the entire product portfolio, with a CSR bonus, but it also demands considerable care and caution. Following a vocal CSR strategy is particularly suitable for companies with a focused product portfolio. Thus Coca-Cola-a major consumer of water resources-participates in initiatives to conserve fresh water in collaboration with Greenpeace, and the global delivery company TNT has established a program to address world hunger through improved logistics.

Such a focus on specific CSR-related issues still can generate stakeholder skepticism toward the company and blur its potential advantages. Walmart may have established "an image of good corporate citizenship, supposedly encouraging its managers to get involved in local communities and through contributions to charity," ${ }^{61}$ but the company faces recurrent criticisms and attacks from various 
stakeholder groups that regard Walmart's tactics as anticompetitive and harmful to local business communities. In response to such criticisms, Walmart has opted for an even more aggressive stance in communicating its CSR messages and engaged in broad advertising and communication campaigns that detail the company's CSR story and CSR successes, with the claim that "Walmart is Working for Everyone." This publicization of the company's positive work environment has prompted some stakeholder groups to adopt an even more critical stance toward the company. As an example of an escalating process, this scenario demonstrates the need for more than good public relations to make CSR initiatives and corporate CSR brands relevant for long-term business value.

\section{Quietly Conscientious}

Many companies tout their CSR activities, hoping for protection for or improvements to their corporate reputations and brand value. Others go the opposite route, perhaps out of fear that such publicity will invite criticism, as experienced by Walmart and others, or because they operate in markets or industries with lower visibility. In the latter case, they likely are subject to less stringent stakeholder demands, perhaps because they function in business-to-business settings. ${ }^{62}$ They work quietly in the background to reduce carbon emissions, find alternative sources of supply, change how their current suppliers work, revamp production processes, or create stringent ethical and social standards. None of these companies explicitly makes sustainability part of its brand, though all of them work hard to minimize their negative social and environmental impacts or contribute to the benefit of society. ${ }^{63}$

Quietly conscientious companies are well aware that CSR efforts do not add brand value for everyone; sometimes CSR benefits only the local community or local employees. These benefits still may create brand value at the corporate level though, because they enhance corporate reputation and image, which helps the company attract talented people and investors, as well as maintain good relationships with business partners. ${ }^{64}$ Similarly, CSR efforts that benefit the environment can invoke brand value at the product level, because they may minimize costs or improve quality. ${ }^{65}$ For such quietly conscious companies, limited and specific communication and dialogue must target appropriate stakeholder groups, whose legitimate claims should be addressed to improve the companies' CSR agenda. For example, DHL, the global express shipment and logistic company, revamped its brand after a series of acquisitions, focusing clearly on the customer through communications centered on its capabilities and its dedication to customer satisfaction. Its "GoGreen" option, in 2007, also allows customers to offset the $\mathrm{CO}_{2}$ emissions associated with their shipments by supporting alternative vehicle technologies, renewable fuels, solar panels, and reforestation projects. ${ }^{66}$

The Swedish fashion giant Hennes \& Mauritz (H\&M) is another example of a company that, though serious about CSR for many years, did not include its involvement in CSR explicitly in its brand messages. Despite its leading role in a complex and closely scrutinized industry, the company mostly kept CSR messages out of its marketing communications and adopted a more humble CSR 
profile. It believed that its CSR policies and initiatives did not constitute a point of differentiation that would make shoppers choose H\&M over other brands. ${ }^{67}$ Therefore H\&M successfully focused on the needs and key expectations of its target groups by highlighting its ability to offer fashion at a reasonable price. At the same time, the company addressed the transparency and CSR expectations of other stakeholders. Yet in recent years, with increasing consumer awareness of CSR and responsible business practices, H\&M has determined that consumers do not "know enough about what we are and have been doing" and identified communicating about its CSR activities to consumers as "an area where we should maybe improve." ${ }^{68}$ As a result, H\&M underwent a purposeful adaptation to progressively integrate CSR into its branding and reposition its corporate brand, moving away from a quietly conscientious profile toward a CSR performer profile. This adaptation has entailed "communicating more to the customer in a form that the customer is prepared to receive the information and the place where the customer wants to receive it," 69 as well as stimulating increased buy-in and integration of CSR principles from people within the company.

The H\&M experience identifies the need for a dynamic perspective on firms' positions in our CSR framework for brand strategy. No strategic option is set in stone with regard to integrating CSR into the brand.

\section{So .... Where Do We Go Next?}

The insights regarding actual companies' experiences developing a CSR brand add a new perspective to existing anecdotal descriptions of using CSR in a branding context. Faced with multiple choices for implementing a CSR initiative, managers can prioritize strategic brand objectives that allow them to differentiate their brand from competitors' but still consider the social impacts of their choices.

Overall, we assert that "greenwashing" or putting up a façade of good corporate citizenship will fail. Companies that already have recognized the weakness of this option and those founded on sincere CSR principles thus have a significant advantage over those that just recognized the new, green, responsible world. Jumping on the CSR bandwagon is possible, but it takes a lot of determination and commitment, as well as recognition of the high expectations of employees, customers, NGOs, and partners. However, this point is not to imply that every company must become a leader in CSR. Rather, we suggest that companies should evaluate the social, environmental, and compliance issues inherent to their value chains and address them strategically, ideally in a way that builds a competitive advantage and has positive implications for society.

If companies can self-identify their CSR and brand strategies, using the framework we provide in this article, they can develop appropriate management programs that can handle the ambiguity of stakeholder relationships and identitybased conflicts with regard to corporate brand management and their CSR activities. Practitioners then can balance stakeholder tensions and achieve consistency 
in their corporate branding and CSR efforts. We offer four suggestions that practitioners should keep in mind:

- Reduce stakeholder ambiguity by doing as you say. When the CSR notion becomes an integral element of the brand, well-aligned corporate actions and brand promises actually build trust and credibility. A greater focus on long-term relationships and well-anchored CSR principles also helps build emotional connections with stakeholders and attenuates potential conflicts among the multiple CSR-related identities of the company. A strategic approach to CSR therefore requires the close alignment of the company's competitive strategy, CSR initiatives, and business processes throughout the supply chain. In this sense, CSR offers a meaningful way to engage employees, customers, and other key stakeholders, such as the financial community, suppliers, NGOs, retailers, and special interest groups.

- Define your strategic aspiration: Leader or follower. For a sustainable competitive advantage, companies must define the strategic CSR topics that are their main focus, as well as what they want to achieve and whether they want to lead or follow. If they lead, CSR must be their overall strategic driver; otherwise, diverse CSR activities (e.g., environmental protection, social activities, and adherence to defined ethical standards) can be complementary forms of hidden, added value, which are not actively communicated as part of the corporate brand identity.

- Provide necessary resources with a long-term perspective. No company has an exclusive license on doing good. Other companies can freely cite their green and social initiatives, honesty, and transparency, which may make differentiation difficult. Yet practitioners should recognize the possibilities for differentiation that emerge from this broad strategy: Even if they make imitable claims, they must achieve their claimed position, in the context of their own particular circumstances. Companies mobilize their resources in various ways to achieve the same outcomes, which means differences in execution and often subtle, but critical, variations in brand positioning.

- If you get caught in the act: What to do. For a company that promises and fails to deliver on a CSR promise, there are three options: dial back claims, change practices, or refocus the corporate brand.

We illustrate these options using the popular ice cream brand Ben $\&$ Jerry's, known for its funky flavors as much as for its environmental and social responsibility. It was purchased by Unilever, grew rapidly, and in turn suffered accusations of insincerity. Ben \& Jerry's label "all natural" became an obviously false claim; the packaging listed processed and artificial ingredients. Its first option therefore was to remove the label from its packaging, but doing so would have diminished the brand's unique positioning, differentiation, and consumer appeal, likely resulting in the gradual decrease of brand value. Many observers predicted just this outcome of the Unilever takeover. As a second option, the ice cream brand could keep making its "all natural" proposition-despite the significant technical or economic barriers to this choice. A third, perhaps more viable approach allows Ben \& Jerry's to reformulate its brand message to make it clearer and more focused, with a greater emphasis on "doing the 
right thing" and ensuring an overall sense of authenticity. The new brand platform then must convince consumers that this new Ben $\&$ Jerry's is relevant to their needs and desires. At the same time, it should avoid ambiguous claims like "natural" that do not constitute the company's core value. In this case, whatever the company chooses to communicate, it must deliver.

\section{Conclusions}

Over the past few decades, management literature has contributed to defining and characterizing the CSR phenomenon, as well as informing its best practices. However, the development, operationalization, and management of CSR branding, until recently, had remained largely unexplored; in this context, our study offers some central contributions.

First, we present a practical, comprehensive model that consolidates theoretical perspectives and empirical insights into robust guidelines for addressing CSR strategically according to four different approaches. These approaches are defined in terms of the level of involvement, level of integration, and key initiators and drivers of the CSR focus. Furthermore, this model indicates that CSR-related research must develop practice-oriented models to determine how organizations engage in and encourage corporate responsibility commitments. ${ }^{70}$ Our proposed model provides a strong basis for further research, especially studies pertaining to the change strategies an organization should adopt to design and deploy comprehensive CSR brand leadership strategies.

Second, our study highlights and substantiates converging managerial and strategic implications of CSR and corporate marketing trends. Both for CSR and corporate marketing, recent conceptualizations emphasize the increasing importance and relevance of adopting a broader stakeholder orientation. Firms must develop appropriate mechanisms to support and coordinate this orientation, as well as perceive corporate actions more broadly and beyond a traditionally profit-based, shortterm focus. By approaching CSR and corporate branding through an identity-based, cultural lens and maintaining a strong focus on field practices, our empirical study addresses the need to investigate the relationship between CSR and corporate identity (expressing cultural understandings). Our findings thus tend to support the argument that the "ethical identity" that supports CSR-related corporate branding initiatives is "formed externally, or relationally between parties, with conceived identity as the critical element affecting its configuration and maintenance." ${ }^{71}$ That is, to reach the potential rewards associated with the development of CSR-related corporate brands, companies need to engage intensively in relational and dialogical processes with their primary and secondary stakeholders. Through such engagement, they can understand both the way they are perceived by stakeholders and the actual expectations in the environment. Formal and informal stakeholder dialogue processes should reduce potential conflicts among the multiple entities and foster internal adaptations that help the company demonstrate its credibility. To achieve this goal, all of the company's levels and functional areas must work in concert.

Third, our empirical, strategic CSR brand framework contributes to extant business and society literature. For example, social responsiveness might involve 
a continuum (reaction, defense, accommodation, and proactivity) that characterizes the extent to which companies react to the social expectations of their environment. ${ }^{72}$ Such strategies for social responsiveness in turn might reflect posturing concepts-that is, the level of responsibility that a company accepts for managing and responding to stakeholders' concerns and relationships. Defined by the company's character in interactions and its responses, ${ }^{73}$ a posture toward social responsiveness typically evolves as the company confronts new issues and challenges. Our identification of four CSR brand strategies at the corporate level builds on these notions. We suggest that distinct corporate postures toward social responsiveness-which are intrinsically linked to what we describe as the level of involvement of the company-typically are associated with specific options in terms of corporate branding. As we show, multiple CSR-related corporate branding and communication possibilities sometimes can characterize a similar level of CSR involvement by the company. The choice thus depends on the company's context, objectives, CSR integration level, and initiators and drivers.

\section{Notes}

1. D.J. Aaker and E. Joachimsthaler, Brand Leadership (London: Simon \& Schuster, 2000); J.M.T. Balmer, K. Fukukawa, and E.R. Gray, "The Nature and Management of Ethical Corporate Identity: A Commentary on Corporate Identity, Corporate Social Responsibility and Ethics," Journal of Business Ethics, 76/1 (November 2007): 7-15; M.J. Hatch and M. Schultz, "Bringing the Corporation into Corporate Branding," European Journal of Marketing, 37/7-8 (July/August 2003): 1041-1064.

2. A. Prakash, "Green Marketing, Public Policy and Managerial Strategies," Business Strategy and the Environment, $11 / 5$ (September/October 2002): 285-297.

3. A. McWilliams and D. Siegel, "Corporate Social Responsibility: A Theory of the Firm Perspective," Academy of Management Review, 26/1 (January 2001): 117-127; M. Van Marrewijk, "Concepts and Definitions of CSR and Corporate Sustainability: Between Agency and Communion," Journal of Business Ethics, 44/2 (May 2003): 95-105.

4. M.B.E. Clarkson, “A Stakeholder Framework for Analyzing and Evaluating Corporate Social Performance," Academy of Management Review, 20/1 (January 1995): 92-117.

5. J.M.T. Balmer, S.M. Powell, and S.A. Greyser, "Explicating Ethical Corporate Marketing. Insights from the BP Deepwater Horizon Catastrophe: The Ethical Brand that Exploded and then Imploded," Journal of Business Ethics, 102/1 (2011): 1-14; A. Lindgreen, V. Swaen, and W.J. Johnston, “Corporate Social Responsibility: An Empirical Investigation of U.S. Organizations," Journal of Business Ethics, 85/2 (April 2009): 303-323; G. Palazzo and K. Basu, "The Ethical Backlash of Corporate Branding," Journal of Business Ethics, 73/4 (July 2007): 333-346.

6. E. Maio, "Managing Brand in the New Stakeholder Environment," Journal of Business Ethics, 44/2-3 (May 2003): 235-246.

7. Clarkson (1995), op. cit.; T. Donaldson and L.E. Preston, "The Stakeholder Theory of the Corporation: Concepts, Evidence, and Implications," Academy of Management Review, 20/1 (January 1995): 65-91; S. Waddock, "Integrity and Mindfulness: Foundations of Corporate Citizenship," in J. Andriof and M. McIntosh, eds., Perspectives on Corporate Citizenship (Sheffield: Greenleaf Publishing, 2001), pp. 26-38.

8. B. Brüggenwirth, "The Brand Positioning Grid," in J. Jonker and M. de Witte, eds., Management Models for Corporate Social Responsibility (Heidelberg: Springer, 2006): 140-146; A. Torres, Tammo H.A. Bijmolt, and J.A. Tribó, "Generating Brand Equity through Corporate Social Responsibility to Key Stakeholders," Economics Working Papers 1209, Barcelona, Department of Economics and Business, Universitat Pompeu Fabra, 2010.

9. T. Kitchin, "Corporate Social Responsibility: A Brand Explanation," Journal of Brand Management, 10/4 (May 2003): 312-26.

10. See for example J. Yan, "Corporate Social Responsibility and the Brands of Tomorrow," Journal of Brand Management, 10/4-5 (May 2003): 290-302; T. Melo and J.J. Galan, "Effects of Corporate Social Responsibility and Brand Value," Journal of Brand Management, 18/6 (April 201 1): 423-437. 
11. J.M.T. Balmer, "Corporate Identity and the Advent of Corporate Marketing," Journal of Marketing Management, 14/8 (November 1998): 963-996; J.M.T. Balmer, "Corporate Identity, Corporate Branding and Corporate Marketing: Seeing through the Fog," European Journal of Marketing, 35/3-4(March/April 2001): 248-291; J.M.T. Balmer, “Identity Based Views of the Corporation: Insights from Corporate Identity, Organisational Identity, Social Identity, Visual Identity and Corporate Image," European Journal of Marketing, 42/9-10 (September/October 2008): 879-906.

12. J.M.T. Balmer, "Corporate Marketing Myopia and the Inexorable Rise of a Corporate Marketing Logic: Perspectives from Identity Based Views of the Firm," European Journal of Marketing, 45/9-10 (September/October 2011): 1-30.

13. Ibid.

14. J.M.T. Balmer and S. Greyser, eds., Revealing the Corporation: Perspectives on Identity, Image, Reputation, Corporate Branding, and Corporate-Level Marketing (London/New York: Routledge, 2003); J.M.T. Balmer and S.A. Greyser, “Corporate Marketing: Integrating Corporate Identity, Corporate Branding, Corporate Communications, Corporate Image and Corporate Reputation," European Journal of Marketing, 40/7-8 (July/August 2006): 730-741; Melo and Galan, op. cit.; Yan, op. cit.

15. Balmer (2011), op. cit.

16. N. Ind, The Corporate Brand (New York, NY: New York University Press, 2001).

17. S. Knox and D. Bickerton, "The Six Conventions of Corporate Branding," European Journal of Marketing, 37/7-8 (July/August 2003): 998-1016.

18. J.M.T. Balmer and E. R. Grey, "Corporate Brands: What Are They? What of Them?" European Journal of Marketing, 37/7-8 (July/August 2003): 972-997.

19. J.M.T. Balmer and A. Wilson, "Corporate Identity: There Is More to It Than Meets the Eye," International Studies of Management $\theta$ Organization, 28/3 (Fall 1998): 12-31.

20. Balmer (2011), op. cit.

21. Hatch and Schultz (2003), op. cit.

22. K.L. Keller and K. Richey, "The Importance of Corporate Brand Personality Traits to a Successful $21^{\text {st }}$ Century Business," Journal of Brand Management, 14/1-2 (September 2006): 74-81.

23. J.M.T. Balmer, H. Stuart, and S.A. Greyser, "Aligning Identity and Strategy: Corporate Branding at British Airways in the Late $20^{\text {th }}$ Century," California Management Review, 51/3 (Spring 2009): 6-23.

24. Balmer (2001), op. cit.

25. Ibid.

26. M.J. Hatch and M. Schultz, "Are the Strategic Stars Aligned for Your Corporate Brand?" Harvard Business Review, 79/2 (February 2001): 129-134; Hatch and Schultz (2003), op. cit.

27. Balmer and Greyser (2003, 2006), op. cit.

28. Balmer and Grey (2003), op. cit.

29. See <www.yoplait.com/Slsl/default.aspx $>$.

30. M. Kalligeros, "Choose Wisely: Partnering for Cause-Related Marketing," PR Tactics, 12/8 (August 2005): 18; H. Pringle and M. Thompson, Brand Spirit: How Cause-Related Marketing Builds Brands (Chichester: John Wiley \& Sons, 2001).

31. K.S. Jahdi and G. Acikdilli, "Marketing Communications and Corporate Social Responsibility (CSR): Marriage of Convenience or Shotgun Wedding?" Journal of Business Ethics, 88/1 (August 2009): 103-113; I. Maignan and O.C. Ferrell, "Corporate Social Responsibility and Marketing: An Integrative Framework," Journal of the Academy of Marketing Science, 32/1 (January 2004): 3-19; B. Parguel, F. Benoît-Moreau, and F. Larceneux, "How Sustainability Ratings Might Deter 'Greenwashing': A Closer Look at Ethical Corporate Communication," Journal of Business Ethics, 102/1 (2011): 15-28.

32. B. Van de Ven, "An Ethical Framework for the Marketing of Corporate Social Responsibility," Journal of Business Ethics, 82/2 (October 2008): 339-352.

33. S. Miller, "Green Toyota Ads Launch into a Hostile Environment," Brand Week, November 5, 2007, <www.brandweek.com/bw/news/recent_display.jsp?vnu_content_id=1003668303>.

34. Palazzo and Basu, op. cit.; C. Fisher-Buttinger and C. Vallaster, Connective Branding: Building Brand Equity in a Demanding World (London: John Wiley \& Sons, 2008).

35. Van de Ven, op. cit.

36. G. Palazzo and A. Scherer, "Corporate Legitimacy as Deliberation. A Communicative Framework," Journal of Business Ethics, 66/1 (June 2006): 71-88; A. Scherer and G. Palazzo, “Towards a Political Conception of Corporate Responsibility: Business and Society Seen from a Habermasian Perspective," Academy of Management Review, 32/4 (2007): 1096-1120. 
37. H. Steinmann and A. Scherer, "Corporate Ethics and Management Theory," in P. Koslowski, ed., Contemporary Economic Ethics and Business Ethics (Berlin: Heidelberg, 2000), pp. 148-192; M.E. Porter and M.R. Kramer, "Strategy and Society: The Link between Competitive Advantage and Corporate Social Responsibility," Harvard Business Review, 84/6 (December 2006): 78-92.

38. M. Polonsky and C. Jevons, "Global Branding and Strategic CSR: An Overview of Three Types of Complexity," International Marketing Review, 26/3 (November 2009): 327-347.

39. Ibid.; D. Dawkins and S. Lewis, "CSR in Stakeholder Expectations and their Implication for Company Strategy," Journal of Business Ethics, 44/2-3 (May 2003): 185-193.

40. K.M. Eisenhardt, "Building Theories from Case Study Research," Academy of Management Review, 14/4 (October 1989): 532-550.

41. Aaker and Joachimsthaler, op. cit.

42. Eisenhardt, op. cit.

43. S. Spiggle, "Analysis and Interpretation of Qualitative Data in Consumer Research," Journal of Consumer Research, 21/3 (December 1994): 491-503.

44. I.E. Berger, P. Cunningham, and M.E. Drumwright, "Mainstreaming Corporate Social Responsibility: Developing Markets for Virtue," California Management Review, 49/4 (August 2007): 132-157; F. Maon, A. Lindgreen, and V. Swaen, "Organizational Stages and Cultural Phases: A Critical Review and a Consolidative Model of Corporate Social Responsibility Development," International Journal of Management Reviews, 12/1 (March 2010): 20-38.

45. W.M. Greenfield, "In the Name of Corporate Social Responsibility," Business Horizons, 47/1 (January 2004): 19-28; Maon, Lindgreen, and Swaen, op. cit.

46. Fisher-Buttinger and Vallaster, op. cit.

47. Aaker and Joachimsthaler, op. cit.; D.Y. Choi and E.R. Gray, Values-Centered Entrepreneurs and their Companies (New York, NY: Routledge, 2011); E.R. Gray and J.M.T. Balmer, "The Sustainable Entrepreneur," Bradford School of Management Working Paper Series, 04/14. See <www.brad.ac.uk/acad/management/external/pdf/.../Booklet_04-14.pdf>.

48. Patagonia, "Our Reason for Being," <www.patagonia.com/us/patagonia.go?assetid=2047\&ln=24>.

49. M.B. Beverland and S. Luxton, "The Projection of Authenticity: Managing Integrated Marketing Communications (IMC) through Strategic Decoupling," Journal of Advertising, 34/4 (December 2005), 103-116; D. Holt, "Why Do Brands Cause Trouble? A Dialectical Theory of Consumer Culture and Branding," Journal of Consumer Research, 29/1 (June 2002): 7-90.

50. R. Anderson and R. White, Confessions of a Radical Industrialist: Profits, People, Purpose. Doing Business by Respecting the Earth (New York, NY: St. Martin's Press, 2009).

51. R. Amodeo, "Becoming Sustainable: Identity Dynamics within Transformational Culture Change at Interface," unpublished doctoral dissertation, Ann Arbor, MI, Benedictine University, 2005.

52. For additional examples and further discussion, see D.Y. Choi and E.R. Gray, "Socially Responsible Entrepreneurs: What Do They Do to Create and Build their Companies?" Business Horizons, $51 / 4$ (July 2008): 341-352.

53. A.K. Verbos, J.A. Gerard, P.R. Forshey, C.S. Harding, and J.S. Miller, "The Positive Ethical Organization: Enacting a Living Code of Ethics and Ethical Organizational Identity," Journal of Business Ethics, 76/1 (November 2007): 17-33.

54. S. Graves and S. Waddock, "Institutional Owners and Corporate Social Performance," Academy of Management Journal, 37/4 (August 1994): 1034-1046.

55. For a more detailed analysis of the case, see J.M.T. Balmer, "The BP Deepwater Horizon Debacle and Brand Exuberance," Journal of Brand Management, 18/2 (October 2010): 97-104.

56. <http://aveda.aveda.com/aboutaveda/index.asp >.

57. S. Christopherson and N. Lillie, "Neither Global Nor Standard: Corporate Strategies in the New Era of Labor Standards," Environment and Planning A, 37/11 (November 2005): 1919-38; F. Maon, V. Swaen, and A. Lindgreen, "Impact of CSR Commitments and CSR Communication on Diverse Stakeholders: The Case of IKEA," in C. Smith, C.B. Bhattacharya, D. Vogel, and D. Levine, eds., Global Challenges in Responsible Business (Cambridge: Cambridge University Press, 2010), pp. 161-190.

58. Fisher-Buttinger and Vallaster, op. cit.

59. M. LaMonica, "Newsmaker: Stirring GE's Ecomagination," CNET News Interview, CNET News, October 26, 2007, <www.news.com/stirring-ge-s-ecomagination/2008-11392_3-6215496.html>.

60. Ibid.

61. K. Basu and G. Palazzo, "Corporate Social Responsibility: A Process Model of Sensemaking," Academy of Management Review, 33/1 (2008): 122-136; W. Beaver, "Battling Wal-Mart: How Communities Can Respond," Business and Society Review, 110/2 (June 2005): 159-169; L. Roner, "Watching Wal-Mart," Ethical Corporation, May 2005, pp. 16-17. 
62. L. Illia, A. Gonzalez, E. Invernizzi, S. Romenti, and S.C. Zygliodopoulos, "CSR Communication: Cross-National Differences or Global Tendencies," paper presented at 13th ICIG Symposium, 2010, St. Gallen, Switzerland.

63. Fisher-Buttinger and Vallaster, op. cit.

64. B. Arya and G. Zhang, "Institutional Reforms and Investor Reactions to CSR Announcements: Evidence from an Emerging Economy," Journal of Management Studies, $46 / 7$ (November 2009): 1089-1112; D. Greening and D. Turban, "Corporate Social Performance as a Competitive Advantage in Attracting a Quality Workforce," Business and Society, 39/3 (September 2000): 254-280; D. Hess, N. Rogovsky, and T. Dunfee, "The Next Wave of Corporate Community Involvement: Corporate Social Initiatives," California Management Review, 44/2 (January 2002): 110-125.

65. L. DeSimone and F. Popoff, Eco-Efficiency: The Business Link to Sustainable Development (Cambridge, MA: MIT Press, 2000).

66. <www.dpwn.de/dpwn?skin=hi\&check=yes\&lang=de_EN\&xmlFile=2002182>.

67. K.H. Blomqvist and S. Posner, "Three Strategies for Integrating CSR with Brand Marketing," Market Leader (Summer 2004), pp. 33-36.

68. B. Cooper, "Speaking with Style: Ingrid Schullström, CSR Managers, H\&M," Just-Style, November 30, 2009, <www.just-style.com/interview/ingrid-schullstr\%C3\%B6m-csr-manager-hm_id106030.aspx>.

69. Ibid.

70. Maon, Lindgreen, and Swaen, op. cit.

71. Balmer, Fukukawa, and Gray, op. cit.

72. A.B. Carroll, "A Three-Dimensional Conceptual Model of Corporate Performance," Academy of Management Review, 4/4 (October 1979): 497-505; I. Wilson, "What One Company Is Doing about Today's Demands on Business," in G. Steiner, ed., Changing Business-Society Interrelationships (Los Angeles, CA: UCLA Graduate School of Management, 1975), pp. 121-140.

73. Clarkson, op. cit.; D.J. Wood, "Corporate Social Performance Revisited," Academy of Management Review, 16/4 (October 1991): 694-718. 
Copyright of California Management Review is the property of California Management Review and its content may not be copied or emailed to multiple sites or posted to a listserv without the copyright holder's express written permission. However, users may print, download, or email articles for individual use. 